\title{
8
}

\section{Defending Australia's land border: The Australian military in Papua New Guinea}

\author{
Tristan Moss
}

Although no war was fought there after the defeat of the Japanese in 1945, Papua New Guinea (PNG) occupied an important place in Australia's strategic thinking during the early Cold War. Not only was the island seen as a barrier to Australia's enemies, it was also a potential base from which to strike the Australian mainland should it fall. During the 1950s it continued its position as a barrier to invasion against the threat of communist aggression from the north. However, with the Indonesian takeover of West Papua in 1962, Australia, for the first time, shared a land border with a potentially hostile nation, and when Indonesia embarked on its policy of Confrontation with Malaysia the following year, PNG was never far from Australian planners' minds. ${ }^{1}$ As a result, throughout this tumultuous period PNG was closely integrated into Australian strategic thinking and wider planning in the event of a conflict with Indonesia, with Australian forces also drawing on experiences in Borneo against Indonesia to inform their preparations in PNG. At the same time, the Australian Army's units in PNG had a clear peacetime role, helping to

1 Bruce Hunt, Australia's northern shield? Papua New Guinea and the defence of Australia since 1880 (Clayton, Victoria: Monash University Publishing, 2017), xxii. 
patrol the border, gathering topographical and human intelligence, and building relationships with the people on whom they would rely during any war or conflict.

By the 1950s, PNG's geographic importance had long been a significant part of Australian strategic thinking. It was concern about the defence of the Australian mainland that led to the 1888 annexation of Papua, the south-eastern portion of the island of New Guinea. In late 1914, Australia annexed German New Guinea in the country's first military operation of the First World War and demanded that the territory be administered by Australia at the end of that conflict. In Australian defence thinking thereafter, the two separately administered territories of Papua and New Guinea together formed a land barrier to Australia's north and would add depth to Australia's defence. Australian defence of New Guinea would also deny its use by hostile powers, as Germany had threatened. The island, former prime minister Billy Hughes informed the Defence Committee in 1939, would be a 'dagger aimed at the heart of Australia' should it be occupied by a hostile power. ${ }^{2}$ The physical barrier of the PNG landmass, with its rugged terrain and impenetrable jungle, combined with the power of the British (and Royal Australian) Navy, was considered by Australian planners to be a suitable foundation of the nation's defence. ${ }^{3}$

The Second World War undermined the assumption that PNG would be a sufficient barrier without significant defence investment, while at the same time the desperate battles across the Owen-Stanley Range and the campaigns to isolate the Japanese naval base at Rabaul served to reinforce the strategic importance of the island to Australia. The campaigns in the jungle between 1942 and 1945 also forced Australia, like its allies, to come to grips with operating in a tropical environment. While technically and operationally Australia learned that there was 'no black magic' in jungle fighting, this appreciation took time. Adjusting equipment and structures, training troops and learning the quirks of the jungle were all key to this process. ${ }^{4}$ Alongside these efforts, Australia recruited Papua New Guineans to act in a scout and reconnaissance role, thereby lending their indigenous knowledge of the environment to the Allied war effort. The Papuan Infantry Battalion was raised in 1940 and, after serving

2 Cited in ibid., 37.

3 Ibid., 25-46.

4 See John Moremon, 'No "black magic": Doctrine and training for jungle warfare', in The foundations of victory: The Pacific War 1943-44, ed. Peter Dennis and Jeffrey Grey (Canberra: Army History Unit, 2004), 76-85. 
in the Kokoda campaign, were joined by four New Guinea Infantry Battalions by war's end, grouped under the Pacific Islands Regiment (PIR). These battalions saw action in all Australia's campaigns, save that at Milne Bay, and were disbanded at the end of the war. The general demobilisation of the Australian armed forces was the main reason for this. However, Australian civilians and the colonial government (termed 'the Administration' and run by the Department of External Territories in Canberra) were also wary of the threat an armed body of Papua New Guineans might pose to colonial rule.

\section{The Cold War}

It did not take long for the security of PNG, so assured after the unequivocal victory of the Second World War, to be brought into question again. The potential threats of a hostile and newly communist China, a global conflict with the Soviet Union and the spectre of communistinspired insurgencies soon came to shape Australian defence policy. ${ }^{5} \mathrm{PNG}$ remained an Australian responsibility after the Second World War and remained on Australia's strategic doorstep. The Defence Committee, as the body responsible for advising the government on strategic policy, emphasised the role of PNG in safeguarding sea and air communications, and as a final strategic barrier, when formulating its strategic vision for Australia. In this, PNG was considered alongside Australia's north, and in particular the Darwin region. ${ }^{6}$ The regular Australian Army was created in 1947; that year also saw the last company of the PIR disbanded, leaving no combat forces in PNG. The Royal Australian Navy (RAN) maintained a supply base on the strategically positioned Manus Island, inherited from the United States, and the need for additional manpower saw the creation

5 Robert O'Neill, Australia in the Korean War 1950-53, vol. 1, Strategy and diplomacy (Canberra: Australian War Memorial and the Australian Government Publishing Service, 1981), 21-34. For a detailed discussion of Australian defence policy during the late 1940s, see DM Horner, Defence supremo: Sir Frederick Shedden and the making of Australian defence policy (St Leonards, NSW: Allen \& Unwin, 2000), 236-315.

6 See the Defence Committee's 'Strategic basis of Australia’s defence policy' for 1953 and 1956, in Stephan Frühling, A history of Australian strategic policy since 1945 (Canberra: Defence Publishing Service, 2009), 167-246. 
in 1948 of the first Papua New Guinean peacetime unit, the RAN PNG Division. It was not, however, a fighting force, and was instead intended to assist in maintaining the naval base. ${ }^{7}$

By 1950, the absence of combat forces defending PNG worried Australian politicians, expatriates in PNG and the press. One Labor politician, FM Daly, criticised the Menzies Government for leaving the 'practically defenceless' New Guinea 'wide open to infiltration'. Daly pointed particularly to the possibility of Indonesia making good on its claim to neighbouring Dutch New Guinea, reflecting a similar concern in the Defence Committee. ${ }^{8}$ The Australian Administrator, JK Murray, voiced similar concerns, referring to reports that foreign submarines had been spotted in the area. ${ }^{9}$ Murray called for the power to raise emergency units from expatriates in the territory; this was not granted, not least because Murray, as a member of the Department of External Territories, did not have vice-regal powers, as in other colonies.

Both the Army and the Menzies Government agreed that a volunteer force drawn from Europeans in PNG would best serve its interests and approved a Citizen's Military Force battalion in January 1950. Drawing on the lineage of the New Guinea Volunteer Rifles, the Papua New Guinea Volunteer Rifles was to be the first line of defence for the territory. The decision to raise an all-European force also reflected the racialised nature of colonial rule at the time, in which Australians were suspicious of the loyalty of Papua New Guinean soldiers and doubted their capability of serving in a modern army as a result of their supposed inherent racial characteristics. However, while Australians in PNG had clamoured for improved defences, they were less enthusiastic when it came to surrendering their own time to serve in part-time military, and recruitment rates were disappointing. While better than having no force there at all, the unit's effectiveness was hampered by its small size, and the fact that it would be scattered around PNG in small depots, unable to fight as a coherent whole.

7 For an overview of the RAN PNG Division see James Sinclair, To find a path: The Papua New Guinea Defence Force and the Australians to independence, vol. 2, Keeping the peace, 1950-1975 (Gold Coast: Crawford House Press, 1990), 179-80.

8 'New Guinea defenceless', Townsville Daily Bulletin, 16 August 1950. See also "'Defence lack in N. Guinea”', The Courier-Mail, 16 August 1950. See also 'New Guinea defence: Infiltration reports', The West Australian, 5 August 1950; 'New Guinea defence: Liberal M's HR critical', The West Australian, 17 August 1950; 'Measures to stop Reds in N.G.', The Advertiser, 20 March 1951.

9 Taylor to Morgan, 30 May 1949, National Archives of Australia (NAA): MP729/8 37/431/114; JK Murray to Secretary External Territories, 16 July 1950, NAA: A5954 2331/9. 
Almost immediately, the Defence Committee recognised that a regular force was also needed. The dispatch of an Australian infantry battalion to Port Moresby was out of the question. The outbreak of the Korean War in June 1950, the need to maintain a reserve on mainland Australia and the cost of sending Australian troops and their families to PNG in peacetime all mitigated against such a move. Equally, in late 1950 only three infantry battalions existed. Papua New Guinean troops, however, represented an inexpensive means by which to defend Australia's north, as they could be paid and equipped at a lower rate compared to Australia-based units.

The postwar PIR was raised in mid-1951 around a cadre of Papua New Guineans who would later form many of the non-commissioned officers for the battalion. The first commanding officer, Lieutenant Colonel Herbert Sabin, arrived on 2 October 1951, and the PIR achieved its full establishment of around 600 Papua New Guineans in November 1952. The unit made use of the wealth of infrastructure remaining from the Second World War in PNG, establishing itself on the site of a former hospital at Taurama, about 8 kilometres from Port Moresby. ${ }^{10}$ Newer materials were scarce, however, and soldiers were housed in tents while huts were built.

The reraised battalion had its role shaped by the Second World War. In the event of war in the 1950s, the PIR was to fight as a reconnaissance and raiding force that was auxiliary to Australian-manned Army units. The battalion would form the initial tripwire should an enemy invade PNG, fighting to delay the enemy and trading space for time in PNG's difficult geography. Once troops were deployed from the mainland, Papua New Guinean soldiers would act as a reconnaissance force for the rest of the Australian Army, with subunits attached to Australian battalions. Small groups from the PIR were also to conduct long-range fighting patrols. ${ }^{11}$ The PIR was structured as a battalion, with four companies of infantry, and the equivalent of two companies of administration troops. However, with these roles, it was not intended to fight as a complete unit. Indeed, the battalion never trained as a whole during the 1950s. Moreover, the PIR was established on a 'light scale', lacking the heavier infantry weapons allocated to the battalions of the Royal Australian Regiment, such as medium machine guns, mortars and anti-tank weapons. ${ }^{12}$ This unique

10 Seacombe to AHQ, 'Construction of a Permanent Barracks - Pacific Islands Regiment - Moresby', 9 March 1951, NAA: MT1131/1 A259/47/3.

11 Jeffrey Grey, The Australian Army (Melbourne: Oxford University Press, 2001), 194.

12 Northern Command, 'Proposal for a New Lower Establishment to Supersede II/23C/2 (LE)', 27 July 1956, NAA: A6059 21/441/15. 
structure reflected the rugged nature of the Papua New Guinean terrain, in which heavy weapons were difficult to move and supply. But it also stemmed from an Australian perception, rooted in racism, that Papua New Guineans were unsuited to managing these more technical weapons, and other equipment, such as radios. ${ }^{13}$

While the PIR was reraised to defend Australia's north, its existence cannot be divorced from the colonial context. In creating the PIR, the Australian Army reflected and sometimes reinforced the colonial structures of PNG - themselves based in radicalised conceptions of Papua New Guineans. In addition to different rates of pay, Papua New Guineans were not permitted to rise above the rank of sergeant during the 1950s. Their conditions were also substantially different to those allocated Australian troops in the territory: their rations consisted of only seven items, and they were not regularly issued with shoes until $1962 .{ }^{14}$ Nonetheless, the PIR represented a popular occupation in PNG, and many young Papua New Guineans joined what they considered to be an elite group. This elitism was at the heart of two euphemistically termed 'disturbances' during the unit's first decade, which saw some of the unit march out of barracks in 1957 to clash with other Papua New Guineans over supposed insults to the regiment, and again in 1961 over the difference in pay between the Army and their traditional rivals in PNG, the police. Despite some hysterical reactions on the part of the colonial authorities, neither of these incidents was directed at Australian rule. ${ }^{15}$

\section{Confrontation}

By the 1960s, the Indonesian assumption of control of West Papua from the Dutch, long feared by Australia, meant that, for the first time, Australia shared a land border 'with a country whose long term friendship cannot be assumed'. ${ }^{16}$ With Indonesia already having embarked upon

13 Tristan Moss, Guarding the periphery: The Australian Army in Papua New Guinea, 1951-75 (Melbourne: Cambridge University Press, 2017), 33, doi.org/10.1017/9781108182638.

14 Ibid., 92-93.

15 For a detailed discussion of these incidents, see ibid., 42-63.

16 Defence Committee 'Minute No. 4/1963: The Strategic Importance to Australia of New Guinea', 7 February 1963, NAA: A452 1972/4342. See also 'Defence Implications of changes in West New Guinea', October 1962, NAA: A452 1962/7075. Peter Edwards with Gregory Pemberton, The official history of Australia's involvement in Southeast Asian conflicts 1948-1975, vol. 1, Crises and commitments: The politics and diplomacy of Australia's involvement in Southeast Asian conflicts 1948-1965 (North Sydney: Allen \& Unwin in association with the Australian War Memorial, 1992), 200-7, 230-32. 
a policy of Confrontation with Malaysia, and by extension the British Commonwealth, the Defence Committee feared that Indonesia might turn its attention towards PNG. The series of Indonesian raids in Brunei in December 1962, and increased activity along the border in Borneo, raised the possibility of similar incursions into Australian territory. Although the distance from Indonesian bases and the difficult terrain made such action less likely - and unlikely at the same scale - as against Malaysia, the Defence Committee nonetheless worried about Australia's ability to respond. This was partly related to the overall size of the Australian armed forces at the time, and in 1963, the committee believed the Australian armed forces were too small to 'make an effective and sustained contribution to SouthEast Asia and at the same time deter Indonesia from possible activities inimical to our strategic interest'. ${ }^{17}$

The Menzies Government was acutely aware of the changed strategic situation, and the growing demands placed on the armed forces, which had already deployed troops to the Far East Strategic Reserve and trainers to Vietnam. The armed forces, and in particular the Army, had little flexibility to meet any crises that, as in PNG, now looked more likely. ${ }^{18}$ In May 1963 the Menzies Government announced an increase in defence spending, including the purchase of additional Mirage fighters and transport aircraft for the Royal Australian Air Force (RAAF), ships and an extension of the fixed-wing capability for the RAN, and an increase of the regular Army to 28,000 soldiers. ${ }^{19}$ In PNG, the Menzies Government's expansion focused on creating layers of defence against Indonesia and other hostile forces. Australia's ability to detect threats was improved through the establishment of an intelligence capability in the territory, which would 'provide warning of infiltration or subversion'. ${ }^{20}$ Coastal security was to be provided on a permanent basis with the creation of a Papua New Guinean patrol boat squadron, which would be based at the naval base at Manus Island under the RAN. With PNG's long coastline, this capability was essential in detecting Indonesian incursions and helping to move patrols around the country. Australia's strike capability in the territory was to be improved through the upgrading of Boram airfield

17 Defence Committee Minute, 4 February 1963, NAA: A1945/40 832/8, cited in DM Horner, Strategic command: General Sir John Wilton and Australia's Asian wars (Melbourne: Oxford University Press, 2005), 203.

18 Ibid.

19 Ibid., 203-5.

20 Defence Committee, 'Minute No. 5/1963: Territory of Papua/New Guinea - Immediate Defence Measures', 7 February 1963, NAA: A452 1972/4342. 
at Wewak to help make the area a suitable base on the northern coast from which the defence forces could operate, or stage further afield. ${ }^{21}$ Previously, aircraft operating out of Jackson Field at Port Moresby had a limited loiter time over the border; now, they would be far closer.

The most significant expansion of Australia's military capability in PNG was found in the PIR. Following the recommendations of Defence, Cabinet authorised the expansion of the PIR from its peacetime establishment to a full battalion, supported by an increase in pioneers, signals and supply troops. A larger training depot was also to be created to support this expansion, which would make the PIR a far more well-rounded and capable force. The Defence Committee saw this as but the first of a series of steps that it, and the Army, had long advocated. The second step included raising another battalion and additional support units. To support these two battalions, an expanded headquarters formation was to be created and a building program to be instituted to house new personnel and their dependants. In the third and final phase, a third battalion would be raised and existing support units expanded. ${ }^{22}$

The PIR did not have to wait long to advance to the second phase of its expansion. In 1964, in response to Indonesian attacks in Borneo, the Menzies Government authorised the use of Australian units along the Thai-Malaysian border, and in August Australian troops helped round up Indonesian infiltrators on the Malay Peninsula. Vietnam also became of increasing concern to the government. In response, the Menzies Government again announced an expansion of the armed forces, part of which was the introduction of national service to help meet its varied commitments. ${ }^{23}$ As part of these preparations, the government authorised the PIR to proceed to expand to three full battalions. The Army's units in PNG were to achieve their full complement of around 3,500 troops by 1968 , necessitating a sizeable increase in recruiting and training. ${ }^{24}$ The airfield at Nadzab, outside Lae, was also to be improved to take Mirage fighters. ${ }^{25}$

21 Cabinet Submission No. 603, 23 March 1963, NAA: A5619 C174; Cabinet Decision No. 791, 8 May 1963, NAA: A5619 C174.

22 Defence Committee, 'Minute No. 5/1963: Territory of Papua/New Guinea - Immediate Defence Measures', 7 February 1963, NAA: A452 1972/4342.

23 Edwards with Pemberton, Crises and commitments, 303.

24 'List of past, current and proposed strengths of PIR -1965', n.d., NAA: A452 1966/4989.

25 'Prime Minister's Statement on Defence: Full re-assessment of the needs', The Canberra Times, 11 November 1964. 
The PIR's expansion occurred more quickly than the Army had planned or hoped for. By 1964, the PIR grew from 660 to 810 Papua New Guineans, along with over 100 Australian troops. The following year, another 700 Papua New Guineans had been recruited and were in various stages of training. ${ }^{26}$ In 1965, PNG Command was created, which reflected the growing strategic importance of PNG to Australia. Where the previous PNG Military District had been subordinated to Northern Command, based in Brisbane, the Army elevated PNG to equal footing with other regional commands. The creation of the PNG Command also expanded Army capabilities in PNG, particularly in the raising of an engineer component, vital in undeveloped PNG. Reflecting its new size and importance, a brigadier, AL McDonald, was appointed PNG Command's first commander.

The second battalion of the PIR (2PIR) was formed in 1965 by splitting the first battalion in half. While this diluted the skill base of the PIR, it was a step towards greatly expanding the Army's capability in PNG. Given the pace of expansion, and the continuing threat from Indonesia, the Army operated under the assumption that the third battalion would be raised and planned accordingly. 2PIR was based at Wewak on the PNG north coast, next to the airfield at Boram, providing a northern base of operations. With third base planned for PNG's second largest city, Lae, on the country's east coast near the proposed fighter-capable airport at Nadzab, the Army could cover the breadth of PNG. The size and location of the PIR was not the only change made: rather than be an auxiliary force to Australian units, during the early 1960s, the PIR was expected to be able to fight alongside Australian-manned forces, at least in the PNG context. This was as much a product of changes in the status accorded Papua New Guineans under Australian rule as it was one of Australia's defence needs. This shift was swift, mirroring and building on shifts occurring in race relations in PNG.

In its combat role, the PIR continued its earlier focus on reconnaissance and patrolling forces, but began to be equipped and trained to take on additional roles. The three PIR battalions were to be based on a more lightly equipped 'tropical' version of standard Australian infantry battalions. In contrast to the 1950 s, this reflected the terrain and likely roles of the battalions, rather than the supposed capabilities of the 
Papua New Guineans within them. The battalions consisted of four rifle companies, but with increased support company capabilities, particularly the mortars and machine guns, and also larger signals and administration subunits. ${ }^{27}$ Heavy equipment, such as anti-tank weapons and trucks were omitted from the PIR's establishment; operating in the jungle, the PIR would fight with what it could carry.

\section{Peacetime operations}

Patrolling made Papua New Guinean units unique within the Australian Army, in that they had an ongoing operational peacetime responsibility alongside their wartime roles. Aside from training for an actual outbreak of conflict, during the early 1960s the PIR's peacetime role was border surveillance, in order to deter and detect Indonesian incursions. It did so by mounting patrols from outstations. On the north coast, this was the permanent Vanimo outstation, while in the south, PNG Command made use of temporary bases as required. Vanimo usually accommodated an infantry company and supporting troops, and saw its airfield and barracks expanded throughout the early 1960s. It was not fortified, in contrast to the entrenched bases used by Australian forces in Borneo during Confrontation. Rather, during peacetime it provided a jumpingoff point for patrols of the northern border region; indeed, at any one time, a significant portion of the infantry company based there would be in the jungle.

The patrols mounted from Vanimo and other bases were the bread and butter of PNG Command. These had three goals: training for war, laying the groundwork for any conflict, and detecting and deterring Indonesian incursions. Patrolling was a substantial commitment of resources, and PNG Command planned each year's training and other activities around them. ${ }^{28}$ Tensions with Indonesia caused a threefold increase in patrolling man-days, from around 9,000 in 1964 to over 30,000 in 1965, a sign of the importance of this activity. ${ }^{29}$ This equated to between 20 and 50 patrols

27 Sinclair, Keeping the peace, 98.

28 Sio Maiasa, interview with Tristan Moss, 3 August 2013.

29 Northern Command, 'Administrative Appreciation for the Expansion of the Army in Papua New Guinea', 11 January 1965, NAA: J2818, 22/1/7. 
per year in most of PNG's provinces. ${ }^{30}$ The burden of patrolling mainly fell on the two battalions of the PIR, although other subunits also headed off into the jungle. Patrolling was usually based on individual platoons; while whole companies would often patrol, in practice companies would also break into their constituent platoons, operating from a forward base, only concentrating when needed.

While the Defence Committee assumed that Indonesian incursions across the border would be unlikely, the tense situation coupled with the difficulty in actually finding a border in a region with poor maps and Dutch, Indonesian and Australian markers in different locations meant that clashes with Indonesian troops were an ever-present risk. In this sense, Australian patrols not only had the role of detecting and deterring Indonesian forays into PNG but might also spark a conflict by aggressive action. They were instructed to avoid this at all costs. ${ }^{31}$ In the event of Indonesian aggression towards Australian troops, patrol leaders - usually lieutenants - were instructed to retaliate 'with only such force as may be necessary to enable him to ensure the safety of ... [the] patrol'. ${ }^{32}$ Soldiers were ordered to use their arms only if the patrol was directly threatened and there was no other course of action. In 1965, for instance, upon hearing of Indonesian soldiers in a village on the Australian side of the border, the commander of 2PIR, Lieutenant Colonel Donald Ramsay, ordered his patrol commander by radio to delay his approach until the Indonesians had departed. In doing so, a potentially volatile situation was avoided in which, Ramsay admitted, 'there could quite easily have been a firefight'. ${ }^{33}$

In providing an opportunity for realistic training, patrols were also fundamental in preparing the PIR for war. In many ways, patrolling was just like war, without the shooting. Patrols operated in the jungle by themselves for long periods of time, carrying all they needed between resupplies. The climate and the terrain were the same in which the unit would have to operate against Indonesia. Patrols were also an excellent

30 '1967/8 PNG Comd Patrol Programme', 18 May 1967, Papua New Guinea National Archives (PNGNA): 55 52/2/2; 'Papua and New Guinea Patrol and Exercise Programme 1971/1972', 7 April 1971, PNGNA: 1008 52/2/2; 'PNG Land Forces Patrol and Exercise Programme, July 1973 to June 74', n.d., PNGNA: 1008 52/2/2.

31 Defence Committee, Minute No. 74/1963, 'Border Crossings Papua - New Guinea/West Irian',

13 December 1963, NAA: A2031, 74/1963.

32 AHQ Operational Instruction 2/63 PIR, 25 February 1963, NAA: A6059 41/441/124.

33 Sinclair, Keeping the peace, 127-28. 
means to develop and test physical fitness. In addition, patrols had a crucial cartographical function in the poorly mapped border region. Until the 1970s, when the Survey Corps completed a comprehensive mapping program, maps of many areas of PNG were poor. Aerial photos were often obscured by cloud and were less than satisfactory in picking out details such as tracks in the jungle. Some maps of the border region simply included large swathes of blank terrain, for which no topographical information existed. Patrols were therefore a crucial part of the Army's preparations for war and reported on the location of tracks, the 'going', villages and other features.

Patrols also had an important intelligence function and laid the foundations for the relationship with local peoples that would be crucial during wartime. Military-civil relationships were key here, with Army patrols working closely with Administration officers, who were scattered in small numbers around PNG, alongside around 3,100 police. ${ }^{34}$ With good relationships between locals and Australian authorities, Papua New Guineans in crucial areas could provide information on Indonesian activity in the border region and on local geography. They could also be called on to provide fresh food and guides to patrols. Both the Army and the Administration took this relationship seriously lest poor relations lead to 'open hostility during times of peace or war', and troops were under strict instructions to approach locals with respect and not to damage property. ${ }^{35}$ Patrols were also an opportunity to promote the Army in PNG, and to encourage recruits. The Army would often send 'prestige' patrols into certain regions; these were more elaborate affairs that could include the PIR Pipe Band. One such patrol, led by Lieutenant T Holland in 1963, was estimated to have been seen by tens of thousands of people. ${ }^{36}$

\section{Plans for war}

If war was to break out with Indonesia in PNG, it would have done so along the border, and patrols from the PIR would have been the tripwire. These forces were not initially intended to stop the Indonesians. Lacking heavy weapons, and able to trade space for time, the patrols were to

34 PNG Command, 'Papua New Guinea Force Operational Plan 1/66', August 1966, Australian War Memorial (AWM): AWM 122 68/4003.

35 ES Sharp to District Commissioner, 'Tabunomu Complaint - PIR', 29 May 1963, PNGNA: 55 $52 / 2 / 2$.

36 Sinclair, Keeping the peace, 93. 
retire in the face of an Indonesian incursion. Only later, once it was determined that a hostile incursion was underway, would concerted action be launched. During war, PNG Command's principal role was to meet and repel border incursion or, if such action was beyond its capacity alone, to contain any threat until assistance could be provided from mainland Australia. ${ }^{37}$ With the Indonesian takeover of West Papua, Australian plans for the defence of PNG became increasingly specific in focus and were meshed with the broader range of anti-confrontation plans being developed by Commonwealth forces (see Chapter 5, this volume). For PNG, the Defence Committee began developing Joint Service Plan Pygmalion in 1964, refining it over the next two years before the end of Confrontation caused it to be downgraded to a general contingency plan.

Plan Pygmalion focused on the threat of Indonesian raids across the border. At the height of Confrontation, PNG Command assessed that, at short notice, the Indonesians could deploy two companies of infantry, around 250 marines, and a company of police along the border area, from a total Indonesian force in West Irian of two infantry battalions, one police battalion and other support units. Intelligence officers believed that Indonesian forces would have two courses of action, alongside around 1,500 indigenous troops. The first, less overt, manner in which Indonesia might exert pressure was through the encouragement and support of subversive elements in PNG.

Planners feared that trained cadres in West Papua could cross the border to foment disaffection among Papua New Guineans. Indonesian forces might go further, and cross the border to mount raids and sabotage, as they had attempted to do in Borneo (and as Australian forces were doing in Kalimantan). Their options would be somewhat limited, given the scale of the border region, and the logistical difficulties of moving forces in that terrain. Moreover, planners assumed that any Indonesian action would be covert and small, as the country would be unlikely to risk war breaking out over PNG. Limited war was considered more likely to erupt because of action elsewhere, particularly Borneo, but in this scenario, Indonesia would be hard pressed to send additional troops to West Irian. Nonetheless, even small covert raids had the potential to have a significant strategic effect. Indonesia held the initiative, as it was able to choose the time and place of its incursions. Combined with subversive activities,

37 Cabinet Submission No. 118, 'Papua/New Guinea - Military Requirements', 8 April 1964, NAA: A4940 C3436. 
such actions would require the deployment of a much larger Australian force than the Indonesians might field. This would tie up Australian forces needed in Malaysia, Borneo and, from 1965, Vietnam. ${ }^{38}$

Demonstrating that the PIR was now considered capable of performing operations similar to Australian units, the first draft of Plan Pygmalion called for the deployment of two companies of the PIR along the border, supported by an increased RAAF and RAN presence in and around the territory. The Special Air Service, which at the time consisted of a single company, would deploy to augment the PIR's long-range patrolling capability. ${ }^{39}$ The two units had trained together for the first time in 1963, with the PIR giving a good account of itself in an exercise against the special forces unit along the Kokoda Track. ${ }^{40}$ The two other companies of the PIR would be rotated with those resting and training in Port Moresby as necessary. A battalion of the Royal Australian Regiment was only to be sent to PNG if the situation deteriorated and reinforcements were necessary. ${ }^{41}$ Experience fighting Indonesians in Borneo, and the expansion of the PNG Command to include a second battalion in 1965, led planners to expand the initial deployment of Pygmalion to consist of one battalion on either side of the central mountain ranges. This reinforced the plan to raise a third battalion, as this would allow PNG Command to rotate the units through the border without having to rely on infantry battalions from Australia. ${ }^{42}$

While addressing the potential for war in PNG, Plan Pygmalion was written in the broader context of Commonwealth defence and Confrontation; the plan both complemented planning in other theatres, such as Borneo, and also drew lessons from previous encounters with Indonesian forces. ${ }^{43}$ Lieutenant General John Wilton, Chief of the General

38 PNG Command, 'Papua New Guinea Force Operational Plan 1/66', August 1966, AWM: AWM122 68/4003.

39 MF Brogan, 'Plan Pygmalion: Proposed conference at Port Moresby 19 - 21 July 65', 28 June 1965, NAA: A1946 1968/710; Department of Defence, 'Plan Pygmalion', 26 May 1966, NAA: A452 $1972 / 4342$.

40 DM Horner, SAS: Phantoms of war, a history of the Australian Special Air Service, 2nd ed. (Crows Nest: Allen \& Unwin, 2002), 61.

41 Joint Service Plan 'Pygmalion', 9 April 1964, NAA: A452 1972/4342.

42 JPC Report No. 32/1968, 'Future Size and Role of the Pacific Islands Regiment', 10 May 1968, NAA: A8738 39; Cabinet Submission No. 118, 'Papua/New Guinea - Military Requirements', 8 April 1964, NAA: A4940 C3436.

43 Peter Dennis and Jeffrey Grey, The official history of Australia's involvement in Southeast Asian conflicts 1948-1975, vol. 5, Emergency and Confrontation: Australian military operations in Malaya and Borneo 1950-1966 (St Leonards: Allen \& Unwin in association with the Australian War Memorial, 1996), 194. 
Staff in 1963, made a note of the applicability of lessons from Borneo to PNG, particularly in relation to the use of intelligence and coordination between the three services. ${ }^{44}$ Similarly, the importance of cooperation with the civilian administration was emphasised in later command and control arrangements developed by the Joint Planning Committee. ${ }^{45}$ Tactically, the operations envisaged on the border were similar, too. They were to take place at the company or platoon level, with troops patrolling from small bases close to the area of operations. Air support was to be vital, but the war itself was, at its core, an infantry fight. It was also, as in Borneo, a fight over the people. While Australian forces were to defend the border, in particular the 'vulnerable points' at which Indonesians might easily access Australian territory, the protection of Papua New Guineans was of equal importance. ${ }^{46}$

There was one final role for PNG Command. Unlike many other colonial forces, PNG Command had no internal security role. Prior to the Second World War, no military presence was considered necessary by Australian authorities; locally recruited police and armed European civilians had proved sufficient to counter any threats from Papua New Guineans. During the 1950s, broad fears of communist subversion - thought most likely to originate from agitation from European expats - worried authorities, but this constituted an intelligence and policing issue, rather than a military one. The advent of Confrontation and the threat from Indonesia gave the military more of an internal security role. However, this was only envisaged in terms of a war situation, during which specific government legislation would come into effect, specifically the Defence Regulations and the National Security Regulations, which covered threats such as sabotage, prohibited areas, the movement of people, and the control of photography and communications, including censorship. ${ }^{47}$

In 1966, the possibility of civil unrest in PNG led the government to explore the possibility of calling out the Army to support the police as a last resort. The suggestion was met with trepidation at all levels of Defence, due to the lack of training of PNG Command in such operations, and

\footnotetext{
44 Wilton to Sherger, 24 October 1963, NAA: A1946 1968/710.

45 Joint Planning Committee, 'Command and control of Operations in the Territory of Papua and New Guinea', 28 February 1964, NAA: A1946 1968/710.

46 Joint Planning Committee 'An outline plan to meet cover Indonesian activity in Papua/New Guinea', 10 April 1964, NAA: A1946 1968/710; Cabinet Submission No. 603, 23 March 1963, NAA: A5619 C174. Compare for instance the role of Australian forces in Borneo, as described in Dennis and Grey, Emergency and Confrontation, 253.

47 'Draft Plan to Safeguard Internal Security', n.d. [1966], NAA: A452 1964/5917.
} 
the seriousness with which the use of the Army against civilians would be viewed at home and abroad..$^{48}$ There was also concern among some members of the Army that the Administration did not entirely understand the implications of calling out the military, or what constituted a serious enough internal security threat for this to occur. ${ }^{49}$ While the Australian Government came extremely close to calling out the PIR in 1970 over riots in New Britain, troops were never used in this fashion during Australian rule in PNG.

\section{Conclusion}

As Australia became increasingly embroiled in Vietnam, the strategic importance of PNG and the threat of war breaking out there declined. The end of Confrontation with Indonesia in 1966 in particular heralded the lessening of the importance of PNG in Australia's strategic thinking. Although the border region continued to be a point of concern - and patrolling continued - tension dissipated sufficiently for PNG to be downgraded from an area of 'vital' interest, to simply an 'abiding' one by $1973 .{ }^{50}$ Increasingly, the war in Vietnam occupied Australia's attention. While many were keen to do so, the troops of PNG Command were barred from participation in Vietnam, because New Guineans were not Australian citizens, but protected persons under the United Nations Trusteeship provisions governing Australian rule there. ${ }^{51}$ Instead, a focus on preparing the military for independence increasingly occupied the attentions of PNG Command. In the nine years before independence was granted in 1975, the Australian Army embarked on a program of education among its Papua New Guinean soldiers, designed to fashion them into citizen-soldiers of an independent Papua New Guinean state. While the independence of PNG - and the serious problems facing the Papua New Guinean Defence Force subsequently - have dominated the history of this institution, for two decades the Army's units in PNG made a significant contribution to the defence of Australia.

48 CE Barnes, Cabinet Submission, 'Papua New Guinea - Threat to Internal Security', 4 July 1966, NAA: A1945 24/2/28.

49 'Plan to safeguard internal security in the Territory of Papua and New Guinea: Note of discussion in Port Moresby from 28th March to 2nd April 1966', 5 April 1966, NAA: A1945, 24/2/28.

50 'Strategic basis of Australian defence policy', June 1973 in Frühling, A history of Australian strategic policy, 464-75.

51 Lynch to Fox, 25 September 1968, NAA: A452 1966/4989; Ted Diro, interview with Tristan Moss, 31 July 2013; Jack Kukuma, interview with Tristan Moss, 3 August 2013. 
This text is taken from Fighting Australia's Cold War: The Nexus of Strategy and Operations in a Multipolar Asia, 1945-1965, edited by Peter Dean and Tristan Moss, published 2021 by ANU Press, The Australian National University, Canberra, Australia.

doi.org/10.22459/FACW.2021.08 